DOI https://doi.org/10.30525/978-9934-26-038-4-48

\title{
СУЧАСНІ УЯВЛЕННЯ ПРО ПАТОГЕНЕЗ ДИСФУНКЦІЇ УРОТЕЛІЮ В УМОВАХ ПОРУШЕНОГО ЛІПІДНОГО ТА ВУГЛЕВОДНОГО ОБМІНУ
}

\author{
Смірнов С. М. \\ доктор біологічних наук, \\ професор кафедри біології, гістології та ембріології \\ Д3 «Луганський державний медичний університет» \\ Чеберніна I. O. \\ асистент кафедри фармакологї̈, клінічної фармакологї \\ та клінічної фармації \\ Д3 «Луганський державний медичний університет» \\ м. Рубіжне, Луганська область, Украӥна
}

Метаболічний синдром (МC), відомий ще під назвою синдром X, визначається Всесвітньою організацією охорони здоров'я як патологічний стан, що включає в себе інсулінорезистентність, гіперліпідемію, абдомінальне ожиріння та артеріальну гіпертензію [11, с.1]. До цього синдрому включають і альтернативні параметри, такі як центральне ожиріння, мікроальбумінурія, ендотеліальна дисфункція, запалення та протромботичний стан [9, с. 19].

МC чинить пагубну дію на функціонування багатьох органів та систем, оскільки фактори, що грають роль у його патогенезі, можуть бути компонентами формування хронічного системного запалення, яке викликає зміни в системах організму [10, с. 219].

Хронічне запалення, викликане МС, провокує генералізовану дисфункцію, при якій основні патологічні зміни спостерігаються у серцево-судинній системі, підшлунковій залозі та печінці [2, с. 37]. Також під впливом компоненту МС - гіперглікемії - формується комплекс урологічних ускладнень, що отримав назву діабетичної цистопатії, яка, за даними літератури, може бути зумовлена поліурією, ангіопатією, перебудовою рецепторного апарату сечового міхура та зміною чутливості рецепторів [13, с. 94].

Одним із чинників формування діабетичної цистопатії у пацієнтів із МС є дисфункція уротелію, який виконує бар'єрну, захисну, транспортну, секреторну та, навіть, сенсорну функції $[3,4,8]$.

He Q та співавтори у своєму дослідженні відмічали такі гістопатологічні зміни уротелію мишей при МС: наявність включень лецитину, 
гемосидерину та продуктів клітинної деградації в клітинах уротелію та збільшення проліферативного індексу у порівнянні з уротелієм мишей без МС. Автори дослідження відмічали вагому роль у формуванні дисфункції уротелію не лише гіперглікемії, а і дефіциту лептину, який характерний для ожиріння, що є також невід'ємним компонентом МС $[5$, с. 970$]$.

Рецепторний апарат сечового міхура представлений холінорецепторами, адренорецепторами, пуринергічними, пептидергічними, канабіноїдними (СВ1 і СВ2) рецепторами [3, 4].

$\mathrm{M}_{2}$-холінорецептори уротелію в нормі превалюють над кількістю $\mathrm{M}_{3}$-холінорецепторів приблизно у співвідношенні 4:1. Активація $\mathrm{M}_{2}$ холінорецепторів призводить до інгібування активності аденілатциклази, що призводить до розслаблення гладеньких м'язів. Навпаки, активація $\mathrm{M}_{3}$-холнінорецепторів активує процеси фосфоінозитидного гідролізу, що призводить до збільшення надходження кальцію до міоциту та скорочення його [1, с. 327].

При дослідженні рецепторного апарату уротелію в умовах МС відмічається збільшення кількості $\mathrm{M}_{3}$-холінорецепторів порівняно з типом $\mathrm{M}_{2}$, та пуринергічних Р2X3 рецепторів, що призводить до превалювання процесів скорочення над розслабленням у сечовому міхурі та формування одного із компонентів діабетичної цистопатії - гіперреактивного сечового міхура $[7 ; 13]$. Збільшення частки $\mathrm{M}_{3}$-холінорецепторів уротелію пояснює ефективність холіноблокаторів (наприклад, фезотеродину) та ін'єкцій ботулотоксину під час лікування гіперреактивного сечового міхура у хворих на цукровий діабет [12, с. 169].

Sung Dae Kim та співавтори провели дослідження щодо використання агоністів канабіноїдних CB1 рецепторів у хворих на гіперреактивний сечовий міхур, і виявилось, що вони призводять до зниження уретрального супротиву. Відмічено, що роль рецепторів СВ2 не має такого значення у формуванні симптомів гіперактивного сечового міхура, як CB1 [6, с. 121].

Liana Merill та співавтори описали так звану «пов'язану з уротелієм сенсорну мережу». Сенсорні, трансдукційні та сигнальні властивості уротелію здатні впливати на скоротливу активність сечового міхура. Ці властивості можна об'єднати у механосенсорну функцію уротелію, що реалізується в тому числі за допомогою каналів перехідного рецепторного потенціалу (TRP). При активації цих каналів, які експресуються уротелієм, відбувається вивільнення медіаторів, наприклад АТФ. Ця експресія може змінюватися при наявності захворювань сечового міхура, що призводитиме до збільшення вивільнення АТФ [8, с. 194].

Наприклад, поліурія, що викликає перерозтягнення сечового міхура, призводить до підвищення синтезу АТФ клітинами уротелію, що призводить до появи ірритативних синдромів та больових відчуттів $[13$, c. 93]. 
Таким чином, знання патогенетичних особливостей змін уротелію у хворих на МC та/або цукровий діабет дозволяє розуміти причиннонаслідкові зв'язки розвитку діабетичної цистопатії, яка погіршує якість життя хворих із порушенням вуглеводного та ліпідного обмінів. Увага до змін у рецепторному апараті уротелію дозволяє більш ефективно обирати медикаментозну корекцію цього стану.

\section{Література:}

1. Andersson KE. Michel M. Muscarinic Acetylcholine Receptors in the Urinary Tract. Handbook of Experimental Pharmacology, vol 2011. P. 319-344 Springer, Berlin, Heidelberg. https://doi.org/10.1007/978-3-64216499-6_16

2. Donna L Mendrick, Anna Mae Diehl, Lisa S Topor, Rodney R Dietert, Yvonne Will, Michele A La Merrill, Sebastien Bouret, Vijayalaskshmi Varma, Kenneth L Hastings, Thaddeus T Schug, Susan G Emeigh Hart, Florence G Burleson, Metabolic Syndrome and Associated Diseases: From the Bench to the Clinic, Toxicological Sciences, Volume 162, Issue 1, March 2018, Pages 36-42, https://doi.org/10.1093/toxsci/kfx233

3. Fry, C.H. and Vahabi, B. (2016), The Role of the Mucosa in Normal and Abnormal Bladder Function. Basic Clin Pharmacol Toxicol, 119: 57-62. https://doi.org/10.1111/bcpt.12626

4. Guan NN, Gustafsson LE, Svennersten K. Inhibitory Effects of Urothelium-related Factors. Basic Clin Pharmacol Toxicol. 2017; 121(4): P. 220-224. doi:10.1111/bcpt.12785

5. He Q, Babcook MA, Shukla S, et al. Obesity-initiated metabolic syndrome promotes urinary voiding dysfunction in a mouse model. Prostate. 2016;76(11):964-976. doi:10.1002/pros.23185

6. Kim SD, Cho KJ, Kim JC. Expression of cannabinoid 1 and, 2 receptors and the effects of cannabinoid 1 and, 2 receptor agonists on detrusor overactivity associated with bladder outlet obstruction in rats. BMC Urol. 2017; 17(1): p.121. Published 2017 Dec 29. doi:10.1186/s12894-017-0313-4

7. Lee, YL., Lin, KL., Wu, BN. et al. Epigallocatechin-3-gallate alleviates bladder overactivity in a rat model with metabolic syndrome and ovarian hormone deficiency through mitochondria apoptosis pathways. Sci Rep 8, 5358 (2018). https://doi.org/10.1038/s41598-018-23800-w

8. Merrill L, Gonzalez EJ, Girard BM, Vizzard MA. Receptors, channels, and signalling in the urothelial sensory system in the bladder. Nat Rev Urol. 2016;13(4):193-204. doi:10.1038/nrurol.2016.13

9. Metabolic syndrome and diabetes : Medical and surgical management. / Kurian, Marina; Wolfe, Bruce M.; Ikramuddin, Sayeed. Springer New York, 2016. 270 p. 
10. Rochlani Y, Pothineni NV, Kovelamudi S, Mehta JL. Metabolic syndrome: pathophysiology, management, and modulation by natural compounds. Ther Adv Cardiovasc Dis. 2017;11(8):215-225. doi:10.1177/1753944717711379

11. Saklayen MG. The Global Epidemic of the Metabolic Syndrome. Curr Hypertens Rep. 2018;20(2):12. Published 2018 Feb 26. doi:10.1007/s11906-018-0812-z

12. Кузьмин И.В., Аль-Шукри С.Х. Фезотеродин в лечении гиперактивного мочевого пузыря: фармакологические основы и клинические результаты. Урологические ведомости. 2020. Т. 10. № 2. С. 163-171. https://doi.org/10.17816/uroved102163-171

13. Кузьмин И.В., Шабудина Н.О. Патогенетические основы развития диабетической цистопатии. Экспериментальная $и$ клиническая урология. 2014. № 4. С. 92-98. 